\title{
GERAKAN TENTARA 1947-1948: TENTARA PELAJAR DI SIDOBUNDER DAN PASUKAN SILIWANGI DI SURAKARTA
}

\author{
Oleh: Danar Widiyanta dan Djumarwan ${ }^{1}$
}

\begin{abstract}
Abstrak
Dalam periode Revolusi Fisik Indonesia, militer dengan sendirinya memainkan peran sentral dalam mempertahankan kemerdekaan Indonesia. Pada periode ini banyak sekali intrik-intrik yang melekat pada wajah militer Indonesia. Artikel ini hendak 'merekam' dinamika sejarah militer yang terjadi di Indonesia selama kurun waktu 1947 - 1948, menjelang Agresi Militer Belanda II. Dalam artikel ini akan ditampilkan dinamika militer yang terjadi pada peristiwa Tentara Pelajar (TP) di Sidobunder dan insiden Pasukan Siliwangi di Surakarta. Kedua peristiwa ini mempunyai karakteristik masing-masing, yang berbeda satu dengan yang lainnya.
\end{abstract}

Kata kunci: revolusi fisik, Tentara Pelajar, Pasukan Siliwangi.

\section{A. Latar Belakang}

Perjuangan rakyat Indonesia belum berakhir dengan dibacakannya Proklamasi Kemerdekaan pada 17 Agustus 1945. Kekalahan Jepang pada Perang Dunia II menyebabkan Belanda kembali untuk mengambil alih Indonesia. Di satu sisi, Indonesia telah memproklamasikan kemerdekaannya, sementara di sisi lain, Belanda merasa berhak mengambil alih wilayahnya dari pihak yang kalah perang. Kedatangan Belanda memunculkan konflik, karena rakyat Indonesia tidak menginginkan negara lain menguasai Indonesia kembali. Perlawanan rakyat menolak terulangnya kolonisasi terjadi di berbagai daerah di Indonesia. Dua contoh perlawanan dari Rakyat terhadap kedatangan kembali Belanda yaitu perlawanan Tentara Pelajar di Sidobunder dan Konflik antara pasukan Siliwangi dan Senopati di Surakarta.

Perjanjian Renville antara Indonesia dengan Belanda mempersempit wilayah kekuasaan Indonesia, serta menimbulkan dua golongan, yaitu yang pro perjanjian dan kontra perjanjian. Sempitnya wilayah Indonesia akibat perjanjian Renville memaksa Pasukan Siliwangi yang

\footnotetext{
${ }^{1}$ Para penulis adalah staf pengajar di Prodi Ilmu Sejarah, Fakultas Ilmu Sosial, Universitas Negeri Yogyakarta.
} 
tinggal di Jawa Barat hijrah ke wilayah yang termasuk kekuasaan Indonesia, karena Jawa Barat menjadi kekuasaan Belanda. Pasukan Siliwangi melakukan perjalanan menuju Jawa Tengah dan Yogyakarta. Pasukan Siliwangi yang sampai di Surakarta bertemu dengan Pasukan Senopati yang merupakan pertahanan Surakarta. Kedua Divisi yang bertemu terjadi kesalahpahaman, yang salah satunya mengenai persetujuan isi perjanjian Renville.

Selain konflik yang terjadi di Surakarta, di Sidobunder juga terjadi pertempuran, antara pihak Indonesia melawan pasukan Belanda. Berbeda dengan konflik di surakarta yang sama-sama melawan pasukan Indonesia, di Sidobunder pelajar-pelajar yang tergabung dalam Tentara Pelajar melawan pasukan-pasukan Belanda yang ingin menguasai kembali Indonesia. Namun, yang jelas kedua peristiwa tersebut menunjukkan bahwa perjuangan rakyat Indonesia tidaklah berhenti setelah proklamasi dibacakan, tetapi perjuangan tetap selalu dilakukan untuk mencegah kolonisasi terjadi lagi di Indonesia.

\section{B. Pertempuran di Sidobunder}

\section{Terbentuknya Tentara Pelajar}

Perjuangan kemerdekaan bangsa Indonesia tidak lepas dari peran pemuda, misalnya Budi Utomo, Perhimpunan Pelajar Pelajar Indonesia (PPPI), Indische Vereeniging, Sumpah Pemuda, dan Tentara Pelajar (TP). Kelompok pemuda yang terakhir, Tentara Pelajar, merupakan kelompok yang berjuang untuk mempertahankan kemerdekaan Republik Indonesia. Tentara Pelajar berada diberbagai wilayah di Indonesia. Sementara itu di Jawa, Tentara Pelajar tersebar di Jawa Barat, Jawa Tengah, Yogyakarta, dan Jawa Timur.

Tentara Pelajar dibentuk di Yogyakarta pada 1943, merupakan organisasi pelajar yang mandiri, awalnya berupa Gabungan Sekolah Menengah Mataram (Gasema). Organisasi ini kemudian diperluas setelah proklamasi kemerdekaan, cakupannya keanggotaannya tidak hanya terbatas pada Sekolah Menengah Mataram, tetapi sampai juga pelajar-pelajar di luar Yogyakarta. Oleh karena itu, untuk mempersatukan seluruh pelajar di Indonesia, maka pada 25 September 1945 diadakan Kongres Pelajar seluruh Indonesia dengan tujuan yaitu: ${ }^{2}$

a. Mengetahui keadaan serta perjuangan di tiap-tiap daerah;

b. Menetukan sukap pemuda dalam menghadapi masa depan;

c. Menentukan persetujuan paham perjuangan rakyat;

d. Mengajak pemuda pelajar memasuki ideology perjuangan rakyat;

e. Mempertebal kekuatan jiwa.

Kongres diatas juga membentuk IPI (Ikatan Pelajar Indonesia), dan pada 17 Juli 1946 diresmikan Tentara Pelajar (TP) yang merupakan bagian dari IPI subidang pertahanan. ${ }^{3}$

\footnotetext{
${ }^{2}$ Soebagiyo I. N, Perjuangan Pelajar IPI-IPPI, (Jakarta: Balai Pustaka, 1987), hlm. 24.

${ }^{3}$ Pusat Sejarah dan Tradisi ABRI, Peranan pelajar dalam Perang Kemerdekaan, (Djakarta: Badan Penerbit Alda, 1985), hlm. 130.
} 
TP terdiri dari beberapa batalyon yang berfungsi menarik pelajar-pelajar di seluruh daerah bergabung. Setiap batalyon terdiri dari beberapa kompi, misalnya Batalyon 300 Yogyakarta terdiri dari Kompi 310, Kompi 320, Kompi 330, Kompi 340, Kompi 350, dan Kompi $360 .{ }^{4}$ Pembentukan batalyon dan kompi untuk mempermudah pengendalian dan pengorganisasian anggota. Susunan seperti itu sama dengan organisasi militer yang terdiri dari Batalyon, kompi, seksi dan regu; setiap batalyon mempunyai susunan staf sesuai kebutuhan. Perbedaan dua organisasi ini adalah mengenai kepangkatan, di Tentara Pelajar tidak ada sistem kepangkatan, sementara di Militer terdapat sistem kepangkatan. Sejak Desember 1946, Tentara Pelajar memiliki Markas Pertahanan Pelajar (MPP), dengan kepengurusannya:

1. Komandan : Imam Slamet

2. Wakil komandan : Suwarto dan Mahatma,

3. Staf : Martono, Suyono, Sukajat dan Sudarma.

Tugas Tentara Pelajar lebih adalah memperkuat pertahanan rakyat, berusaha memperkuat kesatuannya dengan usaha sendiri, membantu membuat senjata, melatih anggota, mengirimkan infiltrasi kedaerah-daerah musuh, dan lain sebagainya. ${ }^{5}$ Tentara Pelajar sering melakukan aksi penyerangan terhadap pasukan Belanda, untuk mengganggu ketenangan dan keamanan pasukan Belanda. Namun demikian, kesulitan perjuangan Tentara Pelajar meningkat ketika Belanda melakukan serangan pada Agresi Militer I, misalnya saja perjuangan Tentara Pelajar di Sidobunder, Kebumen. Perjuangan ini diabadikan melalui tugu yang dituliskan nama-nama pasukan Tentara Pelajar yang menjadi korban.

\section{Perjalanan Tentara Pelajar ke Sidobunder}

Tentara Pelajar Yogyakarta mengirim Kompi 320, terdiri dari dua seksi yaitu seksi 321 dibawah pimpinan Anggoro dan seksi 322 dibawah pimpinan Soedewo, yang masingmasing beranggotakan 60 orang. ${ }^{6}$ Sebelum keberangkatannya, tentara Pelajar dari Yogyakarta tersebut dilatih baris berbaris di Wates dan latihan menembak di pantai Brosot, baru kemudian diberangkatkan ke Karanganyar. Sesampainya di Karanganyar kompi 320 ikut serta mempertahankan kota yang kacau karena ditinggalkan penduduknya yang takut akan kedatangan musuh, terjadi perampokan dan penjarahan di took-toko yang ditinggalkan pemiliknya.

Seksi Sadewo dan Anggoro merupakan seksi pertama yang diberangkatkan, kemudian diberi tugas di Karangannyar. Pada 29 Agustus 1947 pasukan Anggoro diberangkatkan ke desa Sugihwaras, tetapi sebelumnya diperintahkan menduduki Sidobunder, Kecamatan Puring,

\footnotetext{
${ }^{4}$ Sewan Susanto, Perjuangan Tentara Pelajar dalam Perang Kemerdekaan Indonesia, (Yogyakarta: Gadjah Mada University Press), hlm. 23.

5 ibid., hlm. 22.

${ }^{6}$ Satu kompi terdiri dari empat seksi, satu seksi terdiri dari empat regu dan setiap regu terdiri dari 15 orang anggota TP. Lihat juga Paguyuban III-17 Pusat. op.cit., hlm. 33.
} 
Kabupaten Kebumen, sebelah selatan kota Gombong. Pasukan Anggoro berpendapat, medan di Sidobunder berat untuk Tentara Pelajar yang masih minim pengalaman, ${ }^{7}$ tetapi karena merupakan tugas yang harus dilaksanakan, maka Tentara Pelajar tidak bisa menolaknya. Pertahanan Tentara Pelajar di Karangannyar tidak sendiri, karena ada pasukan-pasukan lainnya yang juga memperkuat pertahanan di sana, salah satunya adalah PERPIS (Persatuan Pelajar Indonesia Sulawesi). Sidobunder ditetapkan sebagai pos pertahanan dan Sugihwaras dijadikan daerah basis pertahanan.

Pertahanan di Sidobunder diperkuat dengan bergabungnya Tentara Pelajar Purworejo dan ditambah delapan orang dibagian kesehatan (Palang Hijau). Tentara Pelajar di Sidobunder dibagi menjadi 3 pos, yaitu pos Barat yang merupakan pos terdepan dipimpin oleh Djokomoni; pos Utara di bawah komandi Djoko Pramono; dan pos Selatan dipimpin oleh Suryo Haryono. ${ }^{8}$ Sementara Pasukan Tentara Pelajar tengah menjalankan tugasnya memperkuat pertahanan di Sidobunder, pasukan Belanda telah sampai di Karang Bolong. Pasukan Tentara Pelajar menuggu pasukan Belanda mendekat. Ini menunjukkan kurang pengalaman Tentara Pelajar di medan pertempuran, seharusnya mengetahui keberadaan musuh yang sudah dekat mereka menyusun strategi untuk menghalaunya.

\section{Pertempuran di Sidobunder}

Pada 1 September 1947 tidak terjadi kontak senjata dengan pasukan Belanda di Sidobunder. Pasukan Tentara Pelajar tetap bertugas di pos masing-masing mengantisipasi serangan pasukan Belanda yang secara diam-diam melakukan gerakan dari Karang Bolong dan Gombong menuju Puring. Pasukan-pasukan penembak Belanda secara perlahan menempati titik-titik strategis di pinggiran timur, barat dan selatan Sidobunder, selain itu mata-mata menyamar sebagai penduduk untuk penguasaan medan. Setelah semua pasukan pada posisinya, maka pasukan Belanda telah siap menyerang pertahanan Tentara Pelajar dari segala jurusan.

Di satu sisi, secara personil, pasukan Belanda lebih banyak, yaitu terdiri dari kekuatan satu Batalyon penuh dan perlengkapan senjata cukup besar berupa meriam atau mortar dan tank. Di sisi lain, pasukan Tentara Pelajar berada pada posisi kalah personil, terdiri dari satu seksi dan tambahan pasukan PERPIS satu kompi. Bisa dibayangkan bahwa pasukan Tentara Pelajar secara jumlah, persenjataan, dan strategi kalah dengan pasukan Belanda.

Pada malam hari tanggal 1 September 1947, terjadi hal-hal mencurigakan, diantaranya: Di pos penjagaan bagian Selatan Simpang Tiga Puring-Karangannya-Gombong, La

\footnotetext{
${ }^{7}$ Desa Sidobunder adalah sebuah desa kecil termasuk kecamatan Puring, letaknya kurang lebih $12 \mathrm{~km}$ Barat Daya Karanganyar dan 13 km Tenggara kota Gombong. Bentuknya memanjang dari Utara ke Selatan bergandengan dengan desa Madureja, Purwodadi dan Sidodadi, yang semuanya terpisah oleh sawah yang luas dengan desa Sugihwaras sebagai basis pengunduran front pertahanan.

${ }^{8}$ Mengenai letak pos-pos pertahanan dan markas di Sidobunder, lihat peta.
} 
Sinrang dan Karsono melihat orang berjalan membungkuk di bawah pohon kelapa, ketika mendengar tembakan yang diarahkan kepadanya, orang tersebut melarikan diri; sementara itu di sebelah Barat pertigaan, Joko Sukiman bersama sembilan anggota Tentara Pelajar dari Sulawesi (PERPIS), mendengar suara berulang-ulang yang mencurigakan di dekat kandang dan lumbung padi yang jika didekati suara menghilang. ${ }^{9}$ Selain dua peristiwa tersebut, pada pukul 01.00, Orang berpakaian Jawa mengirimkan kopi panas dan singkong kepada Joko dan teman-temannya dengan permintaan untuk segera dimakan, ${ }^{10}$ karena curiga diracun maka Joko melarang rekan-rekannya yang lain meminum dan memakannya. Kecurigaan itu kemungkinan benar, karena di Puring terjadi kejadian yang sama yang mana tentara jaga di Puring meninggal setelah memakan kiriman, dan kejadian ini menjadikan Puring mudah diinfiltrasi Belanda. Kemudian menjelang pagi, pasukan belanda masuk ke Sidobunder dari arah Timur, menyusup ke bagian Utara desa. ${ }^{11}$

Keberhasilan pasukan Belanda mengepung Sidobunder, menyebabkan Pasukan Tentara Pelajar kalang kabut, sehingga usaha-usaha yang dilakukan pasukan Tentara Pelajar adalah melepaskan diri dari kepungan. Keterbatasan senjata dan pengalaman perang menyebabkan pasukan Tentara Pelajar kewalahan menghadapi kepungan pasukan Belanda, yang dimaksud dengan pasukan Belanda, bukan hanya orang-orang Eropa saja, tetapi ada juga pribumi yang mendukung kembalinya pemerintahan kolonial Belanda.

Pertempuran antara Tentara Pelajar dengan Pasukan Belanda di awali dengan tembak menembak di sekitar Kali Kemit. Sebelum tembak menembak terjadi, Pasukan Belanda telah melakukan pengepungan atas Sidobunder. Mengetahui hal itu, Komandan Djomoko selaku pemimpin regu I, memerintahkan pasukannya untuk mundur ke markas. Tentara Pelajar maupun TNI terkepung dari segala penjuru dan posisi musuh sulit dideteksi karena pasukan Belanda sudah menyelinap masuk desa memanfaatkan alang-alang serta pohonpohon besar yang ada di sekitar desa. Selain telah terkepung, Tentara Pelajar juga sulit membedakan mana lawan dan mana kawan, karena pasukkan Belanda selain dari warganegara Belanda ada juga penduduk Indonesia yang pro dengan Belanda. Pasukan Belanda yang berasal dari bangsa Indonesia terhimpun dalam Koninlijk Nederlands Indische Leger $(\mathrm{KNIL})^{12}$, mereka membela kepentingan Belanda sebagai tentara bayaran.

Banyak korban berjatuhan dari pihak Tentara Pelajar tetapi salah satu Tentara Pelajar bernama Imam Sukotjo berhasil meloloskan diri karena berpura-pura mati di antara jenazah

\footnotetext{
${ }^{9}$ Paguyuban III 17 Rayon Kebumen, Peran Serta Pelajar Pada Masa Awal Perang Kemerdekaan Republik Indonesia, (Kebumen: Paguyuban III 17 Rayon Kebumen), hlm. 39.

${ }^{10}$ Ibid.

${ }^{11}$ Paguyuban Tiga Tujuh Belas, Tentara Pelajar Dalam Perang Kemerdekaan dan Pembangunan, (Jakarta: Yayasan Pengabdian III-17, 1998), hlm. 47-48.

${ }^{12}$ KNIL artinya Tentara Hindia Belanda milik kerajaan (Belanda). Lihat juga Petrik Matanasi, KNIL: Bom Waktu Tinggalan Belanda, (Yogyakarta: MedPress, 2007).
} 
teman-teman seperjuangan setelah kehabisan peluru. ${ }^{13}$ Tentara Pelajar yang selamat, mencari kesempatan untuk mundur ke markas besarnya di Karangannyar. Namun, usaha mencapai markas besar tidak berhasil karena jumlah pasukan dan persenjataan yang tidak seimbang menyebabkan Tentara Pelajar tidak mampu melawan desakan pasukan Belanda yang telah mengepung. Belanda menginstruksikan kepada Tentara Pelajar dan TNI untuk menyerah.

Pasukan Tentara Pelajar yang berhasil meloloskan diri dari kepungan pasukan Belanda, dapat keluar dari Sidobunder dan bergabung dengan pasukan induk di Karangannya. Terdapat 27 Tentara Pelajar hilang; 24 Tentara Pelajar dari Batalyon 300 meninggal dunia; dan 7 dari kesatuan PERPIS. ${ }^{14}$ Menurut kesaksia dari Mad Musin (Rasikun), La Sinrang dan Herman Fernandes, anggota PERPSI, diangkut ke markas Belanda di Gombong, sementara dia sendiri dibawa ke Gombong. ${ }^{15}$ Di Gombong, Rasikun dan Herman dipertemukan, mereka dibawa ke Militaire Politie untuk diperiksa. Herman Fernandes dijatuhi hukuman mati, ${ }^{16}$ sementara La Sinrang dipenjara di Banyuwangi tetapi dapat meloloskan diri. Pelacakan identitas korban baru dapat dilakukan pada 3 September 1946, karena kondisi Sidobunder sudah lebih kondusif pasca pertempuran.

Dampak dari pertempuran di Sidobunder dirasakan baik dari pihak Tentara Pelajar maupun pihak Belanda. Pertempuran yang terjadi di Sidobunder menimbulkan banyak korban dari pihak Tentara Pelajar. Hal itu terjadi karena kalah strategi dan kurangnya latihan. Anggota Tentara Pelajar masih pelajar yang memiliki tugas sebagai pelajar dan belum memiliki pengalaman kemiliteran. Usia mereka berkisar antara 15-22 tahun, bahkan masih ada yang berusia 14 tahun, secara usia masih remaja yang belum waktunya untuk ikut berperang, tetapi keadaan memaksa mereka untuk berpartisipasi dalam perang. ${ }^{17}$ Kondisilah yang memaksa mereka harus ikut ambil bagian dalam pertempuran. Selain menimbulkan banyak korban, pertempuran Sidobunder dijadikan sebagai pengalaman supaya untuk lebih berhati-hati dalam membaca situasi dan kondisi ketika menjalankan tugas, serta untuk tetap semangat meningkatkan kemampuan dalam hal strategi pertahanan.

Sementara itu, di pihak Belanda, sebagai pihak yang menguasai pertempuran, pada pertempuran Sidobunder kehilangan seorang kapten yang ditembak oleh La Sinrang. Menurut kabar resmi dari Belanda mengatakan bahwa 686 orang tentaranya menjadi korban sejak case fire order tanggal 4 sampai 25 September 1947. Jumlah korban mereka menurut pengumuman resminya meningkat dengan 170 orang dalam tempo dua minggu berikutnya. ${ }^{18}$

\footnotetext{
${ }^{13}$ Panitia Sidobunder, Peringatan Palagan Sidobunder, (Kebumen: Paguyuban III-17 Rayon Kebumen, 1984), hlm. 28.

${ }^{14}$ Sewan Susanto, Perjuangan Tentara Pelajar dalam Perang Kemerdekaan Indonesia, (Yogyakarta: Gadjah Mada University Press), hlm. 30-31.

${ }^{15}$ Paguyuban III 17, op. cit., hlm. 30.

${ }^{16}$ Sewan Susanto, op. cit. hlm. 32.

${ }^{17}$ Sewan Susanto, op.cit., hlm. 21.

${ }^{18}$ A. H. Nasution. Sekitar Perang Kemerdekaan Indonesia jilid 6. Bandung: Angkasa. hlm. 18.
} 
Pertempuran Sidobunder bagi pihak Belanda memberi fakta bahwa kekuatan Indonesia di bagian Barat, lemah. Secara kekuatan pasukan Belanda jauh lebih unggul, tetapi mereka gusar melihat perjuangan gigih pihak Indonesia, salah satunya Tentara Pelajar, sehingga meskipun berhasil menaklukkan Sidobunder, tetapi tidak tuntas menghentikan perlawanan dari rakyat. Oleh karena itu mereka berusaha meningkatkan aktivitasnya dalam gerakan pembersihan, terbukti dengan penyerbuan-penyerbuan berurutan setelah pertempuran di Sidobunder. Namun ternyata mereka hanya berkuasa di kota saja, dan daerah-daerah pedalaman masih merupakan wilayah RI, wilayah luas untuk Gerilya yang nantinya akan sangat melelahkan Belanda.

\section{Konflik Pasukan Siliwangi dan Senopati di Surakarta}

\section{Perbedaan Ideologi}

Periode awal tahun 1948, di tubuh Tentara Nasional Indonesia (TNI), sebagai penjaga kedaulatan Republik Indonesia, mengalami keretakan. Persatuan TNI mengalami goncangan, salah satu gambaran terganggunya keharmonisan TNI yaitu terjadinya bentrokan antara Pasukan Siliwangi dan Panembahan Senopati di Surakarta. Konflik antara Pasukan Siliwangi dengan pasukan Panembahan Senopati bermula dari kesalahpahaman terhadap permasalahan ideologi dan politik.

Indonesia, sebagai negara baru, sedang mencari cara mengelola negara. Selain itu, tiga ideologi besar sedang berlomba mencari posisi di Indonesia, yaitu nasionalisme, komunisme, dan islamisme. Ketiga ideologi tersebut menginginkan Indonesia terbebas dari penjajahan kembali Belanda. Konflik Pasukan Siliwangi dan Pasukan Panembahan Senopati merupakan "awal" peristiwa pemberontakan PKI Madiun. Konflik intern TNI ini tidak bisa dilepaskan dari perpolitikan di awal 1948, yang mana terdapat tiga peristiwa penting yakni: Persetujuan Renvile; jatuhnya kabinet Amir Syarifudin; Hijrah Siliwangi; dan berkembangnya komunisme.

Berakhirnya Agresi Militer Belanda I dengan perjanjian Renvile pada 17 Januari 1948, ternyata tidak menstabilkan kondisi keamanan Indonesia karena Indonesia rugi, baik politik maupun militer. Secara politis, wilayah Indonesia berkurang (ada garis status quo); secara militer terdapat beberapa pasal persetujuan gencatan senjata merugikan TNI, misalnya:

"Bahwa terlebih dahulu dan buat sementara waktu akan diadakan bentuk daerah-daerah yang akan dikosongkan oleh tentara (militerized-zone), pada umumnya sesuai dengan garis status quo, tersebut di atas, daerah-daerah itu pada pokoknya mengenai daerah-daerah diantara garis status quo, dan di satu pihak garis kedudukan Belanda yang terkemuka dan di lain pihak garis kedudukan Republik yang terkemuka lebarnya rata-rata daerah itu kira-kira sebanding."19

Peraturan mengenai batas wilayah kekuasaan antara wilayah kedudukan Belanda

\footnotetext{
${ }^{19}$ Dinas Sejarah Militer TNI-Angkatan Darat, 1972, Cuplikan Sejarah Perjuangan TNI-Agkatan Darat, Bandung: Fa. Mahjuma, hlm. 141.
} 
dengan Wilayah Indonesia tentu mengharuskan adanya pemindahan pasukan-pasukan TNI dari luar wilayah Indonesia ke wilayah-wilayah Indonesia sesuai dengan perjanjian Renvile. Pemindahan pasukan diberi waktu 21 hari dari ditandatanganinya perjanjian. ${ }^{20}$ Setelah perjanjian Renvile, pada 23 Januari 1948, kabinet Amir Syarifudin dibubarkan diganti dengan kabinet Hatta. Salah satu kebijakan Kabinet Hatta yang menghangatkan suasana politik adalah Reorganisasi-Rasionalisasi (Re-Ra) di dalam tubuh TNI.

Kebijakan Re-Ra ditentang oleh kelompok PKI dibawah kepemimpinan Muso dan FDR dibawah pimpinan Amir Syarifudin. Kedua kelompok tersebut menggalang kekuatan untuk menentang kebijakan, salah satu caranya dengan mempropaganda politis di dalam tubuh TNI, salah satu sasarannya adalah pasukan Siliwangi yang sedang berhijrah dari Jawa Barat ke Jawa Tengah. Golongan kiri menuduh Pasukan Siliwangi adalah alat pemukul yang dimiliki Kabinet Hatta sebagai pemimpin pemerintahan yang menerima rencana Spoor berupa peleburan TNI dalam KNIL yang komando tertingginya dipegang oleh Jenderal Spoor. $^{21}$

Kondisi politik Republik Indonesia yang fluktuatif dengan naik turunnya suhu politik berbanding lurus dengan silih bergantinya kabinet. Selain itu juga adanya perbedaan ideologi untuk mengelola negara juga merupakan penyebab memanasnya suhu politik. Salah satu ideologi yang terlihat jelas geliatnya adalah gerakan kaum komunis di akhir 1948 dengan kembalinya tokoh komunisnya, Muso, dari Uni Soviet. Pada 11 Agustus 1948, untuk pertama kalinya Muso menginjakkan kakinya lagi di Yogyakarta. ${ }^{22}$ Kali ini ia datang dengan paspor atas nama Suprapto, nama samarannya sebagai sekertaris Supriono, seorang pejabat yang pernah diutus oleh pemerintah RI guna mengadakan perundinganperundingan dengan Uni Soviet. $^{23}$

Geliat kelompok komunis mempengaruhi hijrah pasukan Siliwangi dari Jawa Barat ke Jawa Tengah, yang mana salah satu tujuan pasukan Siliwangi adalah Surakarta. Di Surakarta, terdapat Divisi Panembahan Senopati yang merupakan penjaga pertahanan di wilayah Surakarta. Kedua pasukan tersebut bertemu dan karena adanya kesalahpahaman maka terjadi konflik. Konflik dari dua divisi tersebut hanya melibatkan kesatuan setingkat batalyon.

Panembahan Senopati menjunjung kesetiaan kepada pemimpin sehingga turut mendukung keputusan Letnan Kolonel Soetarto menolak Rasionalisasi yang mana tindakan ini didukung oleh Front Demokrasi Rakyat (FDR) yang merupakan oposisi pemerintahan

\footnotetext{
${ }^{20} \mathrm{Ibid}, \mathrm{hlm} .141-142$.

${ }^{21}$ Himawan Soetanto, Yogyakarta 19 Desember 1948, Jendral Spoor (Operate Kraai) versus Jendral Sudirman (Perintah Siasat No.1), Jakarta: Gramedia Pustaka Utama, 2006. hlm. 148.

${ }^{22}$ Dinas Pembinaan Mental Angkatan Darat. 2008. Hijrah Siliwangi. Jakarta: Dinas Pembinaan Mental Angkatan Darat., hlm. 95.

${ }^{23}$ Dinas Sejarah Militer TNI-Angkatan Darat, 1972, Cuplikan Sejarah Perjuangan TNI-Angkatan Darat, Bandung: Fa. Mahjuma, hlm. 148.
} 
Kabinet Muhammad Hatta. Sementara itu, pasukan Siliwangi sebagai kekuatan militer Kabinet Muhammad Hatta, siap digerakkan ke segala arah untuk melancarkan segala urusan.

Kedekatan FDR dengan Panembahan Senopati yang terjalin sejak adanya rencana Rasionalisasi oleh pemerintah, ${ }^{24}$ sangat diperhitungkan untuk menentang program Re-Ra. Sejak penghujung Februari 1948 telah terjalin kesepakatan diam-diam yang berhasil dicapai antara Panembahan Senopati yang memprediksikan bahwa Rasionalisasi adalah rencana peningkatan kekuatan Kementrian Pertahanan untuk berada di atas kekuatan Militer, dengan FDR yang juga mencari dukungan dan kekuatan untuk mendapatkan kembali kursi kekuasaan. ${ }^{25}$ Kolonel Soetarto selaku panglima Divisi IV Panembahan Senopati, membentuk formasi baru Komando Pertempuran Panembahan Senopati (KPPS).

\section{FDR dan Divisi Panembahan Senopati}

Front Demokrasi Rakyat (FDR) menggandeng Panembahan Senopati untuk membuat kekacauan di Surakarta, dipimpin oleh Kolonel Soetarto dibantu oleh Letnan Kolonel Soeadi, Letnan Kolonel Soejoto dan Letnan Kolonel Jadau. ${ }^{26}$ Kolonel Soetarto merapatkan barisan Divisi IV Panembahan Senopati yang menjadi pengikutnya dan menyingkirkan kelompok pro pemerintah (Kabinet Hatta) yang ada di Surakarta. Beberapa kesatuan tidak tunduk kepada Divisi IV, diantaranya adalah BPRI di bawah pimpinan Letnan Kolonel Mardjuki, Banteng dan Laskar Rakyat yang tergabung dalam Brigade 24 pimpinan Letnan Kolonel Iskandar. Divisi IV melakukan pelucutan senjata kepada kesatuan-kesatuan yang tidak mendukungnya.

Meskipun mendapat perlawanan dari beberapa pihak, program Rasionalisasi tetap dijalankan. Program ini memaksa Soetarto, selaku pimpinan TNI Divisi IV Panembahan Senopati, untuk tunduk kepada Jendral Sudirman yang datang ke Surakarta untuk menemui Soetarto. Akan tetapi kedekatannya dengan FDR, menyebabkan Soetarto masuk ke dalam dafrat yang harus disingkirkan. Kolonel Soetarto dibunuh dengan ditembak di depan rumahnya sendiri di Kampung Timuran pada 2 Juli 1948 pukul $19.30^{27}$

Kolonel Soetarto sebagai Panglima Komando Pertempuran divisi Panembahan Senopati, memiliki pengaruh dan wibawa di kalangan pasukan Panembahan Senopati. Oleh karena itu,

\footnotetext{
${ }^{24}$ Diketahui markas Panembahan Senopati di Solo dihiasi gambar Marx dan Lenin dalam ukuran besar dan pada bendera divisi terdapat gambar bintang merah diatas gambar burung garuda. R.Jokosuyono yang dipilih oleh Amir Syarifudin pada 1946 untuk mengepalai koordinasi kelaskaran dalam Kementrian Pertahanan, sebelum perang adalah anggota SPI Madiun. Merdeka, 4 Juli 1948.

${ }^{25}$ Julius Pour, Ign.Slamet Riyadi; Dari Mengusir Kempetai sampai menumpas RMS, (Jakarta : PT Gramedia Pustaka Utama, 2008), hlm. 24.

${ }^{26}$ ANRI, Laporan mengenai siasat Letnan Kolonel Soejoto untuk merebut (menguasai) Karesidenen Surakarta. 25-9-1948.

27 ANRI, Inventaris Arsip Kepolisian Republik Indonesia 1947-1949 No. 892. Lihat Julianto Ibrahim, Bandit dan Pejuang di Simpang Bengawan; Kekerasan dan Kriminalitas Masa Revolusi di Surakarta, (Surakarta : Bina Citra Pustaka, 2004), hlm. 173.
} 
penembakan terhadap Kolonel Soetarto menimbulkan goncangan di tubuh Divisi Senopati karena kehilangan sosok pemimpin. Setelah itu, Divisi Panembahan senopati semakin tertekan dengan adanya penculikan terhadap perwira-perwira divisinya. Pada 8 September 1948, penculikan terhadap Letnan Kolonel Suherman ketika menjalankan tugasnya untuk memimpin penyelidikan atas peristiwa pembunuhan Kolonel Soetarto; ${ }^{28}$ penculikan berlanjut pada Letnan Kolonel Sumarto $^{29}$,Mayor Esmara Sugeng, Kapten Sutarto, Kapten Supardi, Kapten Suradi dan Letnan Mulyono dari Brigade 9/KPPS, Tentara Laut Republik Indonesia (TLRI). ${ }^{30}$ Pembunuhan dan penculikan yang menimpa divisi Panembahan Senopati menimbulkan berbagai prasangka kepada divisi Siliwangi yang hijrah ke Surakarta. Kecemburuan kepada pasukan Siliwangi juga timbul karena posisi istimewa yang di dapatkan sebagai Batalyon Mobile.

Kebencian Panembahan Senopati terhadap Pasukan Siliwangi meningkat dengan terlibatnya pasukan hijrah itu dalam aksi-aksi kriminal seperti merampok, membeli tanpa bayar dan meresahkan masyarakat Surakarta. ${ }^{31}$ Aksi-aksi tersebut menyebabkan Pasukan Panembahan Senopati mengepung markas Siliwangi dari Batalyon Rukman yang bermarkas di Tasikmadu. ${ }^{32}$ Pasukan Siliwangi melakukan aksi-aksi itu karena kurangnya fasilitas serta persediaan logistik. Komandan pasukan Siliwangi menganggap ini adalah masalah internal kesatuan dan akan diselesaikan sendiri sebagai bentuk otoritas komandan kepada prajuritnya yang tidak disiplin. Pada 24 Agustus 1948 markas Batalyon Rukman diserang oleh pasukan Panembahan Senopati dengan turut mengerahkan kekuatan rakyat. ${ }^{33}$ Serangan Pasukan Panembahan Senopati dapat dipatahkan dan berhasil dipukul mundur. Kemudian, diantara kedua pasukan tersebut melakukan perundingan yang menghasilkan keputusan bahwa Batalyon Rukman dari divisi Siliwangi ditempatkan di luar Surakarta, seperti tuntutan Komando Militer Kota (KMK) Surakarta, STC dan KPPS. ${ }^{34}$ Perundingan ini tidak menghentikan konflik antara Senopati dan Siliwangi.

Perseteruan antara Divisi Panembahan Senopati dan Siliwangi terjadi lagi, disebut peristiwa Srambatan. ${ }^{35}$ Peristiwa ini melibatkan Mayor Slamet Riyadi dan dua Batalyon eks TLRI dengan pasukan Siliwangi kompi Lucas (Kompi Pengawalan Brigade Siliwangi II di bawah pimpinan Kapten Oking) dan dibantu oleh Kompi Komir dari Batalyon 2/Brigade II Siliwangi. ${ }^{36}$ Penyerangan mendadak terhadap asrama Siliwangi dilakukan dari manuver

\footnotetext{
${ }^{28}$ David Charles Anderson, Kudeta Madiun 1948, (Yogyakarta : Media Pressindo 2008), hlm. 33.

${ }^{29}$ Himawan Soetanto, Yogyakarta 19 Desember ; Jendral Spoor (operatie Kraai) versus Jendral Sudirman (Perintah Siasat No.1), (Jakarta : Gramedia Pustaka Utama, 2006), hlm. 197.

${ }^{30}$ Soe Hok Gie, op.cit., hlm 235. Lihat Arsip Kodam VII Diponegoro, Sedjarah Kronologis TNI di Dalam Daerah Karesidenen Surakarta, 7 -9-1948, hlm. 5.

${ }^{31}$ Ibid., hlm. 233.

${ }^{32}$ Ibid., hlm. 233.

${ }^{33}$ Ibid., hlm. 234. Lihat ANRI, Kepolisian Negara No.40. Laporan mengenai siasat Letnan Kolonel Soejoto untuk merebut Karesidenan Surakarta, 26-9-1948.

${ }^{34}$ Himawan Soesanto, op. cit., hlm. 194.

${ }^{35}$ Lokasi penyerangan di Tasikmadu dan Srambatan Kabupaten Karanganyar.

${ }^{36}$ Himawan Soesanto, op.cit .,hlm.195.
} 
latihan pasukan Mayor Slamet Riyadi. Serangan ini didahului dengan keluarnya ultimatum dari Komando Pertempuran Panembahan Senopati ${ }^{37}$ untuk melepaskan perwiraperwiranya yang ditahan di markas Srambatan.

Pasukan Siliwangi di Srambatan merasa tidak terlibat dengan penculikan perwiraperwira dari Divisi Senopati, oleh karena itu, ultimatum tidak dilaksanakan. Kecurigaan mengarah pada Siliwangi karena penculikan perwira-perwira Panembahan Senopati terjadi di dekat Srambatan dimana para tawanan lain juga ditahan disana, dan sepeda dari kelima perwira itu juga ditemukan di dekat Srambatan. ${ }^{38}$ Sampai batas waktu yang ditentukan, tidak mendapat jawaban atas ultimatum yang dikeluarkan maka Letnan Kolonel Soeadi memerintahkan Mayor Slamet Riyadi selaku Komandan Brigade V Panembahan Senopati dan dua Batalyon dari TLRI untuk mempersiapkan diri mengepung asrama Srambatan.

Pasukan Panembahan Senopati yang sudah bersiap di bawah pimpinan Slamet Riyadi menyerang asrama Siliwangi di Srambatan. Pertempuran melibatkan Batalyon TLRI dibawah Tarno Tjakil dari Biro Perjuangan ${ }^{39}$ dan dibantu Komando Pertempuran Surakarta. Pertempuran berlangsung dari pukul 13.00-18.00 diakhiri dengan perintah case fire penghentian tembak-menembak yang dikeluarkan langsung oleh Panglima Besar Sudirman dan setelah Jaksa Agung berhasil menemui pimpinan tentara dan sipil untuk mengadakan perundingan yang kemudian menghasilkan pengumuman bersama Dewan Pertahanan Daerah Surakarta no.12 tahun $1948 .{ }^{40}$ Pada saat tembak-menembak berhenti, pasukan Senopati mencari perwira-perwira mereka yang ditahan, tetapi tidak ditemukan.

Pasukan Siliwangi tidak lagi hanya bertahan, tetapi juga mulai melakukan serangan dengan meminta bantuan dari Batalyon Siluman Merah pimpinan Mayor Achmad Wiranatakusumah, Batalyon Guntur/Brigade Siliwangi I pimpinan Mayor Daeng Mohammad, hizbullah, Barisan Banteng, dan Tentara Pelajar. ${ }^{41}$ Pertempuran terjadi lewat tengah hari dengan melibatkan Kompi Lukas yang bertahan di Srambatan meluas ke Panasan dan Tasikmadu dibantu tiga batalyon dari Yogyakarta melawan Batalyon Digdo dari KPPS dan Batalyon 2 Resimen Jadau yang pro FDR. ${ }^{42}$ Pasukan Siliwangi berhasil menguasai Kota Solo pada 17 September 1948.

Konflik di Surakarta tidak hanya antara Pasukan Siliwangi dan Senopati saja, tetapi

${ }^{37}$ Tanggal 10 September 1948 Komandan Komando Pertempuran Panembahan Senopati mengeluarkan ultimatum kepada kesatuan yang bermarkas di Srambatan setelah peringatan pertama diatas ternyata tidak mendapatkan perhatian. Dalam ultimatum tersebut antara lain dinyatakan "jika sampai dengan tanggal : 13 September 1948 jam 14.00, lima orang perwira TNI (Panembahan Senopati) yang diculik tidak diserahkan kembali kepada KPPS akan diadakan tindakan tegas". Arsip Kodam VII Diponegoro, Sedjarah Kronologis TNI di Dalam Daerah Karesidenan Surakarta.

${ }^{38}$ Julianto Ibrahim, op. cit., hlm. 175.

${ }^{39}$ Julius Pour, Ign Slamet Riyadi dari Mengusir Kempetai sampai Menumpas RMS, (Jakarta: PT Gramedia Pustaka Utama,2008), hlm. 78.

${ }^{40}$ Arsip Kodam VII Diponegoro, Pengumuman Dewan Pertahanan Derah Surakarta no.12 Tahun 1948.

${ }^{41}$ Himawan Soetanto, op.cit., hlm. 198.

${ }^{42}$ Arsip Kodam VII Diponegoro, Sedjarah Kronologis TNI di Dalam Daerah Karesidenan Surakarta. 
juga yang mendukung kedua belah pihak. Misalnya saja, Barisa Benteng bentrok dengan Pesindo yang mendukung FDR. Penggrebekan terjadi pada 9 September 1948 di markas besar Pesindo oleh gerombolan yang diduga Barisan Benteng, menculik 12 orang dan mencuri dokumen-dokumen penting. Dugaan itu kemudian memunculkan aksi balas dari Pesindo dengan menculik Dr. Moewardi pada 13 September 1948; menculik Citromargoso dan Darmosalimin pada 14 September 1948 yang di balas oleh Barisan Benteng dengan menghancurkan markas Pesindo di Singosaren dan di Gladag serta menghancurkan kekuatan dan menguasai markas Pesindo. ${ }^{43}$ Penculikan, Penggrebekan dan pelucutan senjata mewarnai kota Surakarta selama September 1948. Konflik kedua kesatuan berjalan seiring perkembangan situasi dan gejolak politik pemerintahan dan pergerakan FDR yang kemudian secara matang telah mempersiapkan pemberontakan terhadap Republik di Madiun.

\section{Penyelesaian Konflik di Surakarta}

Panglima Besar TNI Jenderal Sudirman selaku pemimpin tertinggi angkatan perang, merasa bingung menghadapi situasi yang terjadi di Surakarta. Hasutan yang memecah belah prajurit merupakan permasalahan yang sulit, terlebih masuk juga paham komunis yang menunggangi konflik. Selain itu kebijakan pemerintah, salah satunya $R e-R a$, merugikan kepentingan tentara. Dilema yang dihadapi oleh pimpinan tentara atas kekacauan di Surakarta tidak hanya melibatkan masalah internal militer semata, namun juga berkaitan dengan isu-isu politik dan isu-isu strategis yang lebih luas. Satu sisi terlihat jelas kemungkinan bahwa FDR/PKI akan mampu menciptakan suasana tenang di Surakarta dan bahkan mungkin akan bertindak sendiri untuk mengupayakan pembebasan para sandera politik dan para perwira PPS yang bersimpati padanya. ${ }^{44}$

Jenderal Sudirman mengambil peran serta dalam upaya penyelesaian bentrokan militer yang terjadi di Surakarta sejak peristiwa pelucutan Mobil Brigade (MOBRIG) oleh pasukan TLRI pimpinan Letnan Kolonel Ahmad Jadau, ${ }^{45}$ peristiwa Tasikmadu antara Batalyon Rukman Siliwangi dengan Batalyon PPS yang diselesaikan secara hierarki militer dengan persetujuan dari kedua belah pihak memindahkan Batalyon Rukman keluar kota Surakarta. Pemindahan Batalyon Rukman ternyata tidak dengan segera menyelesaikan masalah Siliwangi dengan Panembahan Senopati. Contoh lainnya, bentrok di Srambatan pada 13 September 1948 berhasil diberhentikan ketika Jenderal Sudirman mengeluarkan perintah pemberhentian tembak-tembakan.

\footnotetext{
${ }^{43}$ Julianto, op.cit., hlm. 176. Buruh, 17 September 1948. Serangan Barisan Banteng dibantu oleh 2 pasukan dari Siliwangi. George Mc. Turnan Kahin, Refleksi Pergumulan Lahirnya Republik : Nasionalisme dan Revolusi Indonesia (Surakarta: Sebelas Maret University Press, 1995), hlm. 367-368.

${ }^{44}$ David Charles Anderson, op.cit., hlm. 41.

${ }^{45}$ Pelucutan senjata MOBRIG termasuk salah satu langkah FDR menghimpun pasukan yang sepaham dengan tujuan FDR dan menyingkirkan pasukan yang tidak dapat diajak bekerja sama. Dalam, ANRI, Kepolisian Negara no.40, Laporan Siasat Letnan Kolonel Soejoto untuk merebut Karesidenan Surakarta.26-9-1948.
} 
Jenderal Sudirman mengusulkan supaya Pasukan Siliwangi ditarik keluar dari Surakarta. $^{46}$ A.H. Nasution, Letnan Kolonel Sadikin, dan Letnan Kolonel Abimanyu menyatakan bahwa jika pasukan Siliwangi ditarik dari Surakarta akan menimbulkan penafsiran bahwa kehadiran pasukan Siliwangi sudah tidak dibutuhkan dan dimungkinkan akan kembali ke Jawa Barat yang berarti melanggar persetujuan Renville sehingga bisa menjadi alasan Belanda kembali melakukan aksi agresinya.

Panembahan Senopati tetap menjalankan langkah-langkah rasionalisasi meskipun tidak menyetujuinya. Meskipun demikian ada kecurigaan dari A.H. Nasution terhadap Pasukan Panembahan Senopati yang dianggap terdapat personel tentara yang nakal dan telah terpengaruh oleh golongan kiri melalui kursus-kursus politik golongan kiri. ${ }^{47}$ Oleh karena itu dituntut ketegasan dari Jenderal Sudirman mengambil tindakan tegas kepada Panembahan Senopati tanpa perlu adanya Perundingan. Kesulitan Jenderal Sudirman untuk segera menyelesaikan konflik adalah adanya dualisme pimpinan militer yang melemahkan posisi Jendral Sudirman sebagai Panglima Tertinggi TNI karena keberadaannya di bawah Muhammad Hatta sebagai Menteri Pertahanan. ${ }^{48}$ Akhirnya perjanjian damai dilaksanakan di Balai Kota Solo untuk menyelesaikan konflik tetapi menemui jalan buntu. Jenderal Sudirman memutuskan untuk mengadakan penyelidikan atas penculikan perwira-perwira Panembahan Senopati dan seputar peristiwa penyerangan atas asrama Siliwangi di Srambatan, dipimpin oleh Komandan Korps Polisi Militer Kolonel Gatot Subroto ${ }^{49}$ pada 15 September 1948. Langkah penyelidikan dilakukan untuk sedikitnya meredam amarah dari kedua belah pihak yang terlibat konflik.

Selama masa penyelidikan, terjadi konflik antara Pesindo dan Barisan Benteng yang yang saling menggerebek, menculik dan melakukan aksi-aksi kriminal sehingga membuat kacau suasana di Surakarta. Kemudian Jendral Sudirman mengingatkan agar para pemimpin negara dan pemimpin tentara yang telah sepakat mengambil langkah guna menjamin keamanan umum di wilayah Surakarta dan tidak ragu-ragu menerapkannya di daerah Republik lainnya. ${ }^{50}$ Muhammad Hatta dalam menjalankan perannya sebagai perdana menteri berjanji bahwa

\footnotetext{
${ }^{46}$ David Charles Anderson, op.cit., hlm. 35. Soe Hok Gie, Simpang Kiri dari Sebuah Djalan : Kisah Pemberontakan PKI Madiun September 1948, Thesis.M.A . Universitas Indonesia, 1969, hlm. 175-176.

${ }^{47}$ A.H.Nasution, Sekitar Perang Kemerdekaan Indonesia Jilid 8 Pemberontakan PKI Madiun, (Bandung: Angkasa, 1979), hlm. 217.

${ }^{48}$ Bulan Juli dalam aksi pemogokan yang dilakukan oleh buruh perkebunan dan pabrik karung goni di Delanggu, Muhammad Hatta memerintahkan pengiriman pasukan TNI reguler ke wilayah itu tanpa melalui Jendral Sudirman. Berita Indonesia, 16 Juli 1948.

${ }^{49}$ Gatot Subroto dilahirkan pada Oktober 1909 di Purwokerto Jawa Tengah. Pertengahan tahun 1946 Gatot Subroto memimpin Divisi Sunan Gunung Jati, yang merupakan divisi tentara reguler di Purwokerto dan didekati Muhammad Hatta dan Suryadarma pada April 1948 untuk memimpin Corps Polisi Militer (CPM), yang keanggotaannya tersusun atas anggota-anggota terpilih dari kelompok-kelompok polisi seperti Tentara Polisi, Polisi Tentara Laut, Polisi Angkatan Udara dan Pengawas TNI. David Charles Anderson, op. cit., hlm. 39.

${ }^{50}$ Antara, 16 September 1948.
} 
kabinetnya akan mengambil tindakan drastis dalam melawan para pengacau dan pengancam yang menyebarkan propaganda kebencian anti pemerintah yang mengganggu jalannya demokrasi. ${ }^{51}$ Langkah Muhammad Hatta ini tentu sedikit banyak akan menggunakan kekuatan militer untuk menyingkirkan pengacau yang dalam hal ini ditujukan pada golongan komunis FDR dan pasukan Panembahan Senopati yang pro FDR. Pengerahan kekuatan militer dilakukan di bawah komando Jendral Sudirman, namun terjadi krisis kepemimpinan karena pasukan Siliwangi tidak berpihak pada Panglima tertinggi namun berpihak dan bertindak sebagai tentara Kabinet Muhammad Hatta.

Pembicaraan lebih lanjut mengenai penyelesaian permasalahan di Surakarta dilakukan di Yogyakarta oleh Jendral Sudirman, A.H.Nasution dan Kolonel Gatot Subroto pada 16 September 1948. ${ }^{52}$ Pertemuan itu menghasilkan keputusan pengangkatan Gatot Subroto sebagai Gubernur Militer di Surakarta yang berwenang atas semua alat negara serta berhak sepenuhnya menjalankan tugas-tugas dewan pertahanan. ${ }^{53}$ Pengangkatan Gubernur Militer tidak memiliki dasar hukum yang kuat untuk melaksanakan tugas itu, maka dengan persetujuan Presiden dan Kabinet kemudian Gatot Subroto datang ke Surakarta pada 18 September 1948 untuk melaksanakan tugasnya dengan dibantu Letnan Kolonel Bambang Sugeng dan Muljanto Wakil Jaksa Agung sebagai penasehat. ${ }^{54}$ Kolonel Gatot Subroto mengeluarkan intruksi untuk semua angkatan bersenjata di Surakarta agar menghentikan tembak-menembak selambat-lambatnya tanggal 20 September 1948 pukul 24.00. Setiap Komandan pasukan harus menghadap dan melaporkan, dan bagi Komando pasukan yang tidak menghadap dan tidak patuh akan dianggap pemberontak dan akan ditumpas. ${ }^{55}$ Bertepatan dengan keluarnya intruksi tersebut, pasukan Panembahan Senopati yang terlibat pertempuran dengan Siliwangi telah terdesak mundur ke luar kota dan melakukan pemberontakan di Madiun bersama FDR (Pemberontakan PKI Madiun). ${ }^{56}$ Pemberontakan itu memberikan kejelasan bahwa pertempuran di Surakarta itu didalangi oleh PKI sehingga kini jelas bahwa musuh negara adalah PKI. Tanggal 21 September Panglima Pertahanan Jawa Tengah Kolonel Bambang Sugeng bersama Panglima Besar Sudirman datang ke Surakarta untuk menyampaikan perintah dan memberikan penjelasan operasional yang diperlukan. ${ }^{57}$ Kunjungan Panglima

\footnotetext{
${ }^{51}$ Merdeka, 3 September 1948.

${ }^{52}$ Himawan Sutanto, op.cit., hlm. 198.

${ }^{53}$ ANRI. Pengumuman Pemerintah No.1/1948. Pengangkatan Komandan Militer Karesidenan Surakarta. 16 September 1948.

${ }^{54}$ David Charles Anderson, op.cit. , hlm. 42.

${ }^{55}$ Arsip Kodam VII Diponegoro, Pengumuman No.13. Gubernur Militer Surakarta Gatot Subroto. 18-9-1948. Merdeka,20 September 1948.

${ }^{56}$ Dengan keluarnya intruksi Gubernur Militer tersebut, maka pasukan Panembahan Senopati mengalami demoralisasi, dan praktis tidak memiliki pilihan lain, mereka dianggap pengkhianat yang menimbulkan kekacauan di Kota Surakarta, dan jika menghadap sama halnya membawa diri pada penyerahan tanpa syarat kepada pemeritah. David Charles Anderson. op.cit., hlm. 47.

${ }^{57}$ Kedaulatan Rakyat, 23 September 1948.
} 
Besar Sudirman juga menyinggahi markas kesatuan Siliwangi dan Panembahan Senopati untuk menyelesaikan pertikaian antara kedua kesatuan dengan memberikan kejelasan bahwa pertikaian yang terjadi sengaja dibuat oleh PKI yang menginfiltrasikan ideologinya ke dalam tubuh TNI. TNI sebagai tentara negara tidak boleh membela kepentingan golongan manapun dan harus membela kepentingan negara dalam situasi ini TNI kemudian dikerahkan untuk menumpas PKI yang mengacaukan negara.

\section{Kesimpulan}

Perjuangan untuk mempertahankan kesatuan bangsa dan negara tidak hanya untuk tujuan proklamasi kemerdekaan, tetapi perjuangan tetap berlanjut untuk mempertahankan kemerdekaan yang telah dicapai. Kedua peristiwa baik di Sidobunder maupun di Surakarta, merupakan tindakan menentang adanya penjajahan kembali ke Indonesia. Perbedaan kedua peristiwa tersebut, jika di Sidobunder pasukan Indonesia melawan Belanda secara nyata, sementara di Surakarta konflik antar tentara karena adanya kesalahpahaman akibat adanya dampak keberadaan Belanda di Indonesia. Konflik di Surakarta juga adanya campur tangan PKI yang ingin melancarkan keinginannya sehingga memecah belah persatuan TNI.

\section{DAFTAR PUSTAKA}

\section{Arsip:}

Arsip Kodam VII Diponegoro, Pengumuman Dewan Pertahanan Derah Surakarta no.12 Tahun 1948.

Arsip Kodam VII Diponegoro, Sedjarah Kronologis TNI di Dalam Daerah Karesidenan Surakarta.

ANRI, Inventaris Arsip Kepolisian Republik Indonesia 1947-1949 No. 892.

ANRI, Kepolisian Negara no.40, Laporan Siasat Letnan Kolonel Soejoto untuk merebut Karesidenan Surakarta.26-9-1948.

Arsip Kodam VII Diponegoro, Pengumuman No.13. Gubernur Militer Surakarta Gatot Subroto. 18-9-1948. Merdeka,20 September 1948.

ANRI. Pengumuman Pemerintah No.1/1948. Pengangkatan Komandan Militer Karesidenan Surakarta. 16 September 1948.

\section{Surat Kabar:}

Antara, 16 September 1948.

Berita Indonesia, 16 Juli 1948.

Buruh, 17 September 1948.

Kedaulatan Rakyat, 23 September 1948.

Merdeka, 4 Juli 1948.

Merdeka, 3 September 1948.

\section{Buku:}

A.H.Nasution, Sekitar Perang Kemerdekaan Indonesia Jilid 8 Pemberontakan PKI Madiun, (Bandung: 
Angkasa, 1979).

David Charles Anderson, Kudeta Madiun 1948, (Yogyakarta : Media Pressindo 2008).

Dinas Pembinaan Mental Angkatan Darat. 2008. Hijrah Siliwangi. Jakarta: Dinas Pembinaan Mental Angkatan Darat.

Dinas Sejarah Militer TNI-Angkatan Darat, 1972, Cuplikan Sejarah Perjuangan TNI-Angkatan Darat, Bandung: Fa. Mahjuma.

Himawan Soetanto, Yogyakarta 19 Desember ; Jendral Spoor (operatie Kraai) versus Jendral Sudirman (Perintah Siasat No.1), (Jakarta : Gramedia Pustaka Utama , 2006).

Julianto Ibrahim, Bandit dan Pejuang di Simpang Bengawan; Kekerasan dan Kriminalitas Masa Revolusi di Surakarta, (Surakarta : Bina Citra Pustaka, 2004).

Julius Pour, Ign Slamet Riyadi dari Mengusir Kempetai sampai Menumpas RMS, (Jakarta: PT Gramedia Pustaka Utama,2008).

Kahin, George Mc. Turnan. Refleksi Pergumulan Lahirnya Republik : Nasionalisme dan Revolusi Indonesia (Surakarta: Sebelas Maret University Press, 1995).

Panitia Sidobunder, Peringatan Palagan Sidobunder, (Kebumen: Paguyuban III-17 Rayon Kebumen, 1984).

Paguyuban III 17 Rayon Kebumen, Peran Serta Pelajar Pada Masa Awal Perang Kemerdekaan Republik Indonesia, (Kebumen: Paguyuban III 17 Rayon Kebumen).

Paguyuban Tiga Tujuh Belas, Tentara Pelajar Dalam Perang Kemerdekaan dan Pembangunan, (Jakarta: Yayasan Pengabdian III-17, 1998).

Petrik Matanasi, KNIL: Bom Waktu Tinggalan Belanda, (Yogyakarta: MedPress, 2007).

Pusat Sejarah dan Tradisi ABRI, Peranan pelajar dalam Perang Kemerdekaan, (Djakarta: Badan Penerbit Alda, 1985).

Sewan Susanto, Perjuangan Tentara Pelajar dalam Perang Kemerdekaan Indonesia, (Yogyakarta: Gadjah Mada University Press).

Soebagiyo I. N, 1987, Perjuangan Pelajar IPI-IPPI, Jakarta: Balai Pustaka .

Soe Hok Gie, Simpang Kiri dari Sebuah Djalan : Kisah Pemberontakan PKI Madiun September 1948, Thesis.M.A . Universitas Indonesia, 1969. 